\title{
Strategies of Enhancing ICT Use in the Delivery of Management Services in Public Secondary Schools in Siaya County in Kenya
}

\author{
Dr. Dornela Oluoch \\ Mutumbu-Kenya \\ doi: 10.19044/esj.2016.v12n28p375 URL:http://dx.doi.org/10.19044/esj.2016.v12n28p375
}

\begin{abstract}
This study was set to determine the strategies of enhancing ICT use in the delivery of services in public secondary schools in Siaya County, Kenya. Although many secondary schools introduced computers in great numbers starting early 1990s, there are limited information on their use to facilitate delivery of services in school administration and management. The extent to which ICT is being used in school management in secondary schools, the types of administrative uses of ICT by school managers and challenges affecting the integration of ICT in the management systems in secondary schools needed to be adequately addressed. This can only be achieved if there are laid down strategies of enhancing ICT use in the delivery of services in public secondary schools in Siaya County. The study was guided by Social Transformation Theory in Education and Visscher (1992) conceptual model of school information system, which were used to show the relationship between variables. The research design that used was descriptive survey. Questionnaires, Interviews and document analysis were used to collect data. The study established that schools were taking several steps to help in enhancing ICT delivery such as looking for grants from the government, prioritizing purchase of ICT equipment and using parents' involvement to buy computers. The study recommends that effort should be made by the government to post and provide teachers skilled in ICT to each school to impart ICT skills to school managers. The study concludes that more support need to be given to schools to enable them achieve their dream of fully implementing the usage of ICT in the management of school activities.
\end{abstract}

Keywords: Information and Communication Technology (ICT), Strategies and Management Services. 


\section{Introduction.}

The use of Information and Communication Technology (ICT) in schools has become widespread in many countries throughout the world. The extent to which it has been incorporated into the school systems vary widely from simply as a tool to help produce documents to one that is fully integrated into the whole school management practices (Osodo, 2010). Education institutions in Kenya in the $21^{\text {st }}$ century, just as in other parts of the world, are increasingly becoming complex multidimensional organizations requiring tremendous input in terms of human, financial and physical resources. Such school working environments are bound to overwhelm the abilities of today's' teacher and administrator if they are not aided in the performance of their school administrative duties. Therefore, these developments demand that educational institutions modernize their tools of conducting business to enhance the effectiveness of management and leadership. According to Ray and Davis (1991), the potential of information communication and technology (ICT) to enhance human capabilities and revolutionize management of organizations was first realized in other sectors of human society, mostly in the business world and the military, other than in education. The importance of ICT contribution is also widely recognized both in the workplace and at home. These examples are just a few pointers which show that ICT is becoming a vital enabling tool that can no longer be ignored in the management of schools. However, strategies put in place either by the government or school managers to enhance ICT use in the delivery of management services in public secondary schools has not been adequately addressed. Therefore the purpose of the study was to determine strategies of enhancing ICT use in the delivery of management services in public secondary schools in Siaya County, Kenya.

Information Communication Technologies (ICTs) are information handling tools that are used to produce, store and process, distribute and exchange information. These different tools are now able to work together, and combine to form networked world-which reaches into every corner of the globe (UNDP Evaluation, 2001). It is an increasingly powerful tool for participating in global markets, promoting political accountability; improving the delivery of basic services; and enhancing local development opportunities. (UNDP, 2006). According to Ogunsola (2005), ICT 'is an electronic based system of information transmission, reception, processing and retrieval, which has drastically changed the way we think, we live and the environment in which we live.' This therefore means that the governments, schools and individual teachers need to put in place measures for effective management of ICT use in school administration.

Commenting on the relevance of data in the education system, Nwagwu, (1995) argued that effective record keeping is vital to educational 
development. In addition, Nwagwu (1995) emphasized that it will be an impossible task to plan and administer any institution in which records are not kept or are carelessly and fraudulently kept. Consequently, the educational planners and administrators need to have adequate and accurate data of student enrolment and school personnel records for effective planning and management of schools.

One cannot over-estimate the utilization of ICT in everyday activities of the school. Nwosu (2003) noted that ICT assist the school administrators to meet the task of school management in the areas of curriculum and instruction, school community relationship and school business operations. In support of this, Mohammed (2006) argued that the introduction of ICT in schools enhances the daily school routine, programme, solving individuals or groups' as well as staff development.

Gurr (2004) stated that individual centered leadership is no longer appropriate in an educational environment. ICT leadership stems from a shared vision involving the support of the whole school community (Schiller, 2002). ICT allows others to have a greater influence as school leaders. A distributive view of leadership is emerging as a result of ICT integration in schools, further adding to the school leadership reforms. The Principal's delegation of an ICT leader promotes the personal belief in the importance of ICT in the school. The ICT leader as the expert supplies the Principal with advice on ICT. The Principal, with the support of the ICT leader and school community, can develop an ICT vision and e- learning plan, aimed at developing a sustainable direction for ICT in teaching and learning, administration and business of the school organization (Gronow, 2007).

According to Laaria Mingaine (2013), the Government of Kenya recognizes that implementation of ICT in secondary schools will contribute to knowledge production and communication sharing among the school community. This view stems from assertion that's in the literature regarding the importance of ICT in schools (Manduku, Kosgey \& Sang, 2010). The government, through sessional paper no 1 of 2005 noted that ICT has a direct role to play in schools and if properly used, it can bring many benefits to schools as well as to the community. It was noted that ICT will present new opportunities for teaching and learning, and enhancing school management by providing for teacher-to-learners, teacher-to-teacher and learner-to-learner communication and cooperation, enhanced opportunities for several technologies delivered by teachers, creating superior keenness for learning among students and for effective and efficient management (GOK, 2005).

To this end the Government formulated National ICT Policy on education in 2006 with a vision of "A prosperous ICT-driven Kenya Society" and mission "To improve the livelihood of Kenyans by ensuring the availability of efficient accessible, reliable and affordable ICT services” 
(GOK, 2006). The policy highlighted that the government will encourage implementation and use of ICT in schools in order to improve quality of teaching and learning and also to enhance effective and efficient school management system. The policy had come up with several strategies on several areas such as;

- ICT infrastructure: The policy recognizes that lack of adequate ICT infrastructure has hampered provision of efficient and affordable ICT services in the country. The strategy the government has put in place will include provision of support infrastructure such as energy and roads; supporting software development; promotion of local manufacture and assembly of ICT equipment and accessories and; provision of incentives for the promotion of ICT infrastructure.

- Universal access. The policy recognizes that access to ICT services is limited to a few major towns leaving out the rural areas of the country where most Kenyans live. The strategy the government has put in place to enhance universal access will be through; provision of adequate resources to the ICT sector; developing the requisite ICT infrastructure; creating incentives for service providers to deploy services in rural and under-served areas; establish a universal service fund; creating awareness of benefits of ICT to the public; developing knowledge-sharing networks at grassroots level; and creating an enabling environment for Public-Private Partnership (PPP) in ICT development.

- Electronic security. The challenge is for the country to establish an adequate legal framework and capacity to deal with national security, network security, cyber-crime and terrorism, and to establish mechanisms for international cooperation to combat crossborder crimes. An e-security structure will be developed in collaboration with the relevant institutions.

- ICT leadership. There is need for sustained high level ICT leadership and championship at national level to provide oversight inspiration and political goodwill. Effective leadership should facilitate the mobilization of resources needed to develop an ICT environment that is conducive to investment in the country. The government will encourage the sharing of the capacity of public and private utility providers (e.g water, power) that have rights of way to develop the national information infrastructure. The Government will also support the development, deployment and maintenance of multipurpose community, and public library. The Government will encourage the growth of local software industry by increasing awareness among stakeholders of the opportunities offered by different software models, including propriety, open-source and free 
software in order to increase competition, access, diversity of choice and to enable users to develop solutions.

- Human Resource Development. The realization of the policy objectives will depend on the availability and adequacy of skilled human resource capacity. The Governments' strategy will be to; establish educational networks for sharing educational resources; establishing the establishment of ICT centers of excellence; encouraging and supporting IT training for decision-makers, community and civil society leaders; enhancing capacity for research and development in IT.

- Financing Universal Access. The Government expects the private sector to play an important role in meeting the universal access targets through increased investment. The Governments' strategy will be to promote investments in rural and other un-served areas through provision of incentives; a universal service fund for the ICT sector will be set up to complement private sector initiatives towards meeting universal access targets. The purpose of the fund will be to substitute the cost of ICT infrastructure rollout and expansion to unserved and under-served areas by operators in the sector. The fund will also target training in ICT services. Efforts will also be made to identify and mobilize resources from other sources to complement these contributions.

\section{Related Literature}

Globalization and the emergence of knowledge-based economies have forced many countries to reform their education system. According to Al-Sharifa (2012), the enhancement of human capital to meet modern day demands of a knowledge economy, and equip the new generation with the capacity to meet the challenges of the $21^{\text {st }}$ century has become a priority. This challenge is particularly necessary in economies typical of countries, such as Kuwait, which have been dependent on the exploitation of nonrenewable natural resource (Al-Sharifa, 2012).

Transiting from a resource- based economy to an economy based on knowledge and intellectual skills poses a key challenge for an education system. According to Al-Sharifa (2012), significant in the development of this new economy has been the expansion of Information Communication Technology (ICT). In education, in particular, ICT is a tool for transforming the education setting. However, transformation is only successful where there are effective change management strategies and appropriate leadership. At the school level, rapid changes need to be effected in order to change the role that principals take particularly in relation to leading the change process. 
The introduction of computer technology in secondary schools in Kenya is one of the most significant changes in the school system in recent years. The study by Odera (2002) on the role of computers in secondary education found that computers play an important role firstly in school administration to keep school fees records, store information for correspondence and to process examinations. Secondly, it is used for teaching students computer literacy skills and thirdly, it is used for training teachers and community in computer literacy. The other results indicated that principals appreciated the introduction of computers in secondary schools and noted that the school administration reported producing their accounts in an organized manner and more easily than before.

According to Kiplagat (2011), schools are embracing computer technology to complement the traditional classroom learning modes and old traditional, administrative and management practices and therefore both the students and managers need computer knowledge to function. Many challenges face computer and Internet penetration in public schools, including inadequate funds to buy computers, lack of electricity and trained teachers. However, Kiplagat (2011) argues that the progress in schools is still limited. The study further observes that there is a shortage of teachers trained in the use of computer technology. Besides, little investment is being made in relevant computer software for these institutions. There was, therefore, need to investigate further how education managers are trying to embrace the new technology and impediments to its integration in the management in secondary schools.

A related research conducted by Kiptalam \& Rodrigues, (2010) found that with regard to the status of ICT in Kenyan secondary schools, one of the earliest ICT projects in the education sector was implemented by the Aga Khan Foundation (AKF), which was responsible for introduction of computers in Kenya's secondary schools through the Computers in Education Project in Kenya (CEPAK) in 1983. The first phase began with the Aga Khan Academy receiving five computers and the necessary software from AKF according to Makau \& IDRC, (1990). The second phase introduced computers to four public secondary schools in Nairobi. During the three years of this second phase, the project was studied by an independent research team (Makau \& IDRC, 1990). However, this largescale study on the use of computers in secondary schools in Kenya found that computer technology focused majorly in curriculum and not in administrative uses.

A large scale study by School Net (2003) in which 69 secondary schools responded found that only 46 percent of the sampled schools had computers, with availability of Internet and facsimile rare in these schools. The findings also indicated that E-mail was yet to be recognized as a tool for 
collaboration among students and teachers, and only one school had a website while another two reported having networked all their computers to the intranet. It went on to affirm that in these schools, access to the Internet was severely limited and when available was only for administrative use. The study found that almost $40 \%$ of schools had less than 10 computers, and therefore inadequate for teaching and learning. More than 20 per cent had less than 5 computers, indicating that the computers were mostly for administrative use. Only a third of schools studied had dedicated computer laboratories.

Studies conducted by Odera (2002) and Boit and Menjo (2012), in Kenya equally found that effective implementation of computer technology education in secondary schools requires clear policy guidelines of how to integrate the technology in the management of secondary education. The government of Kenya Sessional Paper No. 1 (2005) and ICT draft policy of 2006 on policy framework for Education Training and Research indicate that the government formulated a national ICT policy, and believed that information and communication technology has a direct role to play in education management. According to the draft policy, the government was to provide educational institutions with ICT resources in form of computer hardware, software and ICT teachers. This has not been achieved to any meaningful degree especially in rural schools (Boit and Menjo, 2012). The policy stated that if computer technology is properly used would bring many benefits to the classroom as well as in education in general. The government further stated that the policy on ICT aims to promote and expand its use as a tool for effective management, research and development at all levels of education and use of internet for education, training and research. This research examined strategies examine that have been put in place to enhance ICT use in the delivery of management services in public secondary schools.

Despite significant investment in training and resources, in reality, majority of schools are still far below the level of ICT use. The Ministry of Education in various policy documents articulates the importance and the role ICT could play in education. As an investment, ICT could play an important role by supporting administration, management and decisionmaking in planning and sector policies and strategies delivery (G.O.K, 2005). To demonstrate its seriousness to the goal of ICT integration, the MOE set up a Ministerial ICT Integration Team responsible for the coordination and harmonization of all ICT initiatives. School leaders are critical stake holders in this endeavor. However, there has been a tendency to focus more on infrastructure and model e-schools, than on how school managers use ICT in management practices. The present study, therefore, focused attention on how schools incorporate ICT in their administrative 
systems and how such practices affect their day-to-day management of education.

\section{Research Methodology Research Design}

This study adopted the descriptive survey. According to Mugenda and Mugenda (1999), a descriptive survey involved asking a large group of respondents' questions about particular issues or phenomenon. Descriptive survey was adopted in this study for various reasons. It allowed the researcher to adopt a holistic approach in the study sampled schools. Secondly, it was easy to use research tools like questionnaires and interview schedules.

\section{Location of the Study}

The study was carried out in public secondary schools in Siaya County of Kenya. Siaya County borders Busia County to the North, Kakamega County to the North East, Vihiga County to the East, Kisumu to the South East, with Lake Victoria to the South and West. It has an area of 2,530.5 square km. Poverty level index is $57.9 \%$ (Rural) and $37.9 \%$ (Urban) (Siaya District Development Plan, 2002). Resources available are agricultural land, fisheries, indigenous forests, rivers, and timber. The main economic activities are subsistence farming, livestock keeping, fishing, rice farming and small scale trading. Other economic activities in the County include wage employment, rural and urban self-employment. The County has six Districts namely Gem, Ugenya, Bondo, Siaya, Ugunja, and Rarieda and a total of 167 registered public secondary schools: 16 provincial boys' secondary schools, 20 provincial girls’ secondary schools, 129 mixed public secondary schools, and two national schools (Siaya District Strategic Plan 2005-2010). Literature from Siaya County reveals that while a lot of attention has been directed toward acquisition of ICT equipment, little has been done to integrate them into school management system.

\section{Study Population.}

The study population consisted of all the Principals, Deputies, and Heads of Departments in the examination and boarding section, Secretaries and Bursars/ Accounts' clerks. According to Siaya County Education Report (2011), the estimated registered secondary schools comprised 16 provincial boys' secondary schools, 20 girls' schools, 129 mixed public secondary schools and two national schools, giving a total of 167 public secondary schools. The study selected on the Principals, Deputies, HODs in Examinations and Boarding, Secretaries and Finance officers because these are the key management bodies that run, govern, process and store all the school management documents in secondary school system, be they student 
examinations records, teaching and non-teaching staff records, financial records, boarding records administration, TSC/MOE records among many more records. Therefore the study population was deemed appropriate since it would yield relevant information.

\section{Sample Size and Sampling Techniques.}

43 Educational institutions selected on the criteria of presence of ICT related facilities and indications of ICT use in school management were used in the study. This was done purposively by selecting schools that had incorporated ICT in the delivery of their management systems. Purposive sampling technique was appropriate because according to Kombo and Tromp (2006), it selects participants based on a particular purpose of the study. In this case, it selected participants that had the required information: only those that had incepted ICT in the delivery of management services in secondary schools in Siaya County were used for the study. For each sampled school, saturated sampling technique was used in selecting one principal and one deputy from each sampled school, giving a total of 43 principals and 43 deputies respectively. Saturated sampling technique was convenient because the elements under study are few. A purposive sampling technique was used in selecting one secretary, one Bursar/Accounts' clerk and one Head of Department in the Examinations and one in Boarding Department in each sampled school, giving a total of 43 Secretaries, 43 Bursars/Accounts' clerks, 43 H.O.Ds in the Examinations department, and 43 HODs in the Boarding section respectively. The departments were purposively selected since they document a lot of information regarding other departmental documents and student management records.

\section{Data Collection Instruments}

Data was collected through the use of questionnaires, an interview schedule, and through document analysis. Frankel and Wallen (1993) observe that survey research has four basic way of collecting data namely; administering the instruments " live " to a group; by mail; by telephone and by face to face interview. Face to face interview was used because it helps enlist cooperation of respondents and to establish rapport with them. Borg and Gall (1993) observe that questionnaires are often used to collect basic descriptive information from a large sample while interviews are used to follow up questionnaire schedules. According to Kombo and Tromp (2006), observation schedule allows the researcher to observe the respondents interaction with a given phenomena, idea or a machine, observe the level of expertise and experience with which the respondents handle such like tasks. The researcher therefore collected data using questionnaires, in depth interview schedules and an observation schedule. Questionnaires 
contained both open ended and closed ended items. Frankel and Wallen (1993) observe that closed ended questions are used in research because they are easy to use, score and code for analysis while "open ended" questionnaires allowed for individualized response. In-depth interview was also conducted with school principals. The researcher personally observed the presence of ICT facilities in schools such as printers, cell phones, computers in various departments, information stored on soft and hard copy and the respondents use in computer software packages such as data analysis (spreadsheet and statistical packages), computer data interpretation and computer system management.

\section{Validity and Reliability of Research Instruments}

To ensure the validity of the research instruments, at least two members at the School of Education at Jaramogi Oginga Odinga University of Science and Technology who are experts in this area of study scrutinized the research instruments. According to Mugenda and Mugenda (1999), validity is the degree to which results obtained from the analysis of the data actually represent the phenomenon under study. If such a data is a true reflection of the variables, then the inferences based on such data will be accurate and meaningful. These experts were asked to rate the ability of each item in the questionnaire to measure what it was supposed to in order to get the anticipated data. They also assessed whether the required data would be meaningfully analyzed in relation to the stated objectives and research questions. Therefore, the suggestions of the experts were used in revising the instruments before preparing the final copy.

Reliability refers to the quality of a measured procedure that provides repeatability and accuracy of the research instruments (Gall and Borg, 2006). Therefore, before the instruments are used to collect the data for the study, a pilot study was conducted in three schools that were not selected for the main study: one in mixed school, girls boarding secondary school and the other in boys' secondary school. The pilot study helped to check on the suitability and ambiguity of the research instruments designed, relevance of the information being sought, and level of language used, difficulties the respondents were likely to face when responding to the items, and the content validity of the instruments from the responses given. These results helped in adjusting question sequence, format and content, ensuring the data collection instruments would yield the information required. The questionnaires were administered to deputy principals, Director of studies, clerks/bursars, secretaries and Boarding masters/mistress in secondary schools in Siaya County. To test the reliability of the instruments, the researcher used split - half technique. The instruments were split into two subsets (the sets had odd numbers and even numbers). All even numbered 
items and odd numbered responses in the pilot study were computed separately. By using this method, the researcher aimed at determining the coefficient of internal consistency and reliability co-efficient whose value varied between 0.00 (indicating no reliability) and +1.00 (indicating perfect reliability). The odd numbered scores for all items were correlated with the even numbered scores using Pearson Product Moment Correlation Coefficient of the entire test.

The researcher used Spearman Brown Prophecy formula:

$\frac{2 \times \text { Corr.between the halves }}{1+\text { Corr.between the halves }}$

Or

$$
R e=\underline{2 r}
$$

Where $\mathrm{Re}=$ reliability of the original test

$\mathrm{R}=$ reliability of the co-efficient resulting from correlating the scores of the odd items with the scores of the even items.

A coefficient of 0.70 was considered adequate but a coefficient of 0.80 is good according to Gay (2003). The study achieved a coefficient of 0.727 for teachers' questionnaires which fall between the required range of 0.70- 0.80, hence the instruments were considered reliable.

\section{Data Collection Procedure.}

Permit to carry out the research was sought from the National Council for Science, Innovation and Technology (NACOSTI) through the School of Graduate Studies of Jaramogi Ogimga Odinga University of Science and Technology. Letters notifying various institutions of the intended study were collected by the researcher two weeks before the start of the study. Each of the sampled schools was visited twice or more. The first visit was for introduction, familiarization, and distribution of questionnaires. The second visit was for the interview and collection of filled questionnaires. ). Structured interviews were conducted to 43 principals using face-face conversations. This helped in collecting in depth information that might have not been collected through questionnaire forms. Moreover, interview collected data on emotions, experiences and feelings based on sensitive issues and privileged information from principals (Denscombe, 2000). Appointments were made with principals especially where immediate interview could not succeed due to commitments. This approach was preferred by researchers because it gave the participants a free atmosphere thereby encouraging openness (Kombo, \& Tromp, 2006).

According to Mouly (1993), the questionnaires had a large and representative sample as it was used in a wide geographical area. It assured 
confidentiality which was permanent in the study. It elicited more information and objective replies from participants.

The questionnaires were organized into sub sections; the first section aimed at collecting information on demographic characteristics such as academic qualification and leadership experience and the last section dwelt on the strategies of enhancing ICT use. Questionnaires were distributed to all respondents and were collected after a week by the researcher for analysis.

\section{Data Analysis and Presentation}

Data collected was computerized and analyzed quantitatively by use of statistical package for social sciences (SPSS) Nic Steyn and Bert (2000). The questionnaires were scored and edited, coded and entered into computer for analysis. A code sheet was used for synthesizing data which was analyzed quantitatively because all the data involved in the study could be reduced to numerical values. Quantitative analysis involved getting the total scores of each subject on the study and the presentation of statistical data in the form frequency distribution tables using descriptive statistics. This gave clear picture of the nature, state and strategies put in place to enhance ICT use in the delivery of services in public secondary schools in Kenya. Tabulation for each questionnaire depending on the responses of the study unit was made. Information on strategies put in place to enhance the delivery of management services were analyzed descriptively through percentages, tabulations, means and frequencies. This was done from the H.O.Ds Questionnaire, document analysis and through interview schedules.

Tables and descriptions were categorized depending on the categories of respondents. Information on the availability of computers, computing materials and existing government and school ICT management policies were analyzed through document analysis from various schools and government documents. This was done by drawing tables and listing available documents. They were interpreted as per the research objectives. Documents from various Heads of Departments were also analyzed through tabulations, frequencies, range and mean. Qualitative data from interview schedules from the principals were transcribed, and written in verbatim according to various themes, categories and sub categories as they emerged during the study (Mugenda and Mugenda, 2003). Information on strategies of enhancing ICT in the delivery of services in secondary schools was equally analyzed descriptively. The results were discussed, conclusions made and recommendations made based on study findings.

\section{Research Ethics}

Ethics is perceived as application of moral principals while interacting with others in order to be respectful, fair and to promote healthy 
relations (Borg et el, 2006). The researcher is concerned about ethics so as to be cautious of hurting people who will have something to do with this research work. The researcher abstained from copying or duplicating the work of other researchers for any purpose without prior permission. The researcher equally undertook to explain the purpose of the study and give any information which would increase the willingness of the respondents to participate. The researcher obtained informed consent of the research subjects before they were engaged to participate in the study. The researcher also clarified to the participants that the study was purely for academic purposes and all information collected would be treated with utmost confidentiality. Prior to carrying out the research, permit was sought from National Commission for Science, Technology and Innovation ( NACOSTI), through the school of Graduate Studies of Jaramogi Oginga Odinga University of Science and Technology. Introductory letters notifying various institutions of the intended visit were collected and distributed to the institutions early enough. The researcher was confident that all ethical issues had been put into consideration.

\section{Results and Discussions}

Strategies by the Principals for Enhancing ICT Use in the Delivery of Management Services in Public Secondary Schools.

The study objective was to recommend strategies by the Principals for enhancing ICT use in the delivery of management services in public secondary schools. Data was obtained from all the respondents. Table 1 gives a summary of the findings.

Table 1 Strategies of enhancing ICT use in secondary School

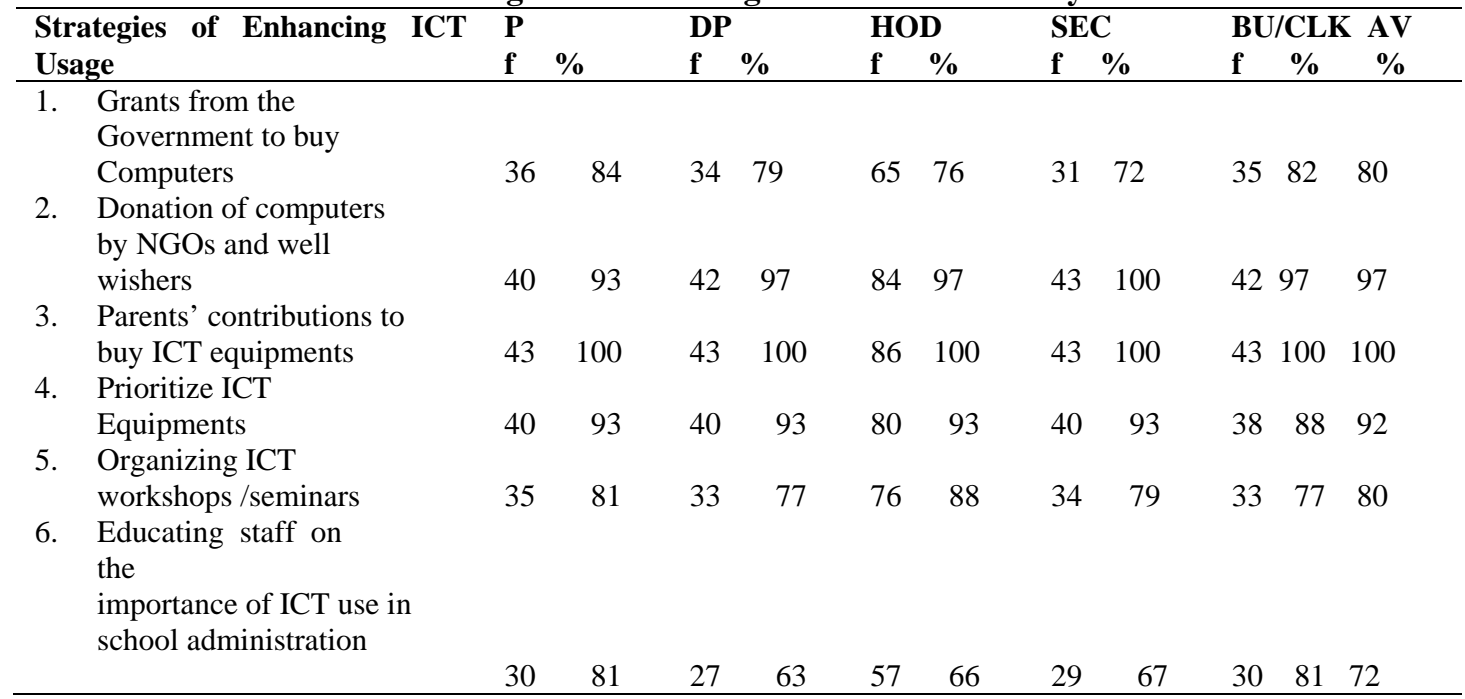

KEY: P= Principals, $\mathbf{D}=$ Deputy Principals, HoDs =Heads of Departments, Sec=Secretaries,

BU/CLK=Bursars/Accounts clerks 
Table 1 reveals that there were several strategies that could be used by schools to enhance the use of ICT in the school management system. Among the major steps were; looking for grants from the government to buy computers, seeking for ICT grants from NGO and using parents contributions for buying computers. Other steps included; prioritizing ICT equipments in the school board of management, organizing workshops on IT and educating the staff on the importance of ICT on the school administration.

During interviews 38 (84\%) principals maintained that they were trying to connect with various NGOs to donate for them computers. The principals also indicated that they were using politicians and other influential people around their schools to connect them with NGOs so that they could get donations of computers. They were doing this so that their schools could be completely interlinked right from the gate to the principal's office. The principals further explained that using ICT in managing institution was a very good way of monitoring all departments while one is inside his/her office.

All the principals concurred that their schools were planning to use parents' contributions for buying computers and other ICT equipments to enable them be interlinked and managed through ICT. The principals also noted that they were intending to use PTA funds to enable the schools purchase the ICT equipments. Nearly all the Principals (100\%) indicated they were negotiating with the PTA Executive to approve the use of PTA Funds in purchasing more computers for school management.

During interviews with principals, the study established that 40 (93\%) of the principals were prioritizing ICT equipments in the school Board of Management. They noted that the board of management was to make their first development agenda for this new financial year. The principals who rated prioritization at 40 (93\%) also added that making purchase of ICT equipment a priority was a noble course towards school progress and development. They added that this was the only way of helping them to adequately monitor and control their schools. The views were shared by 80 Deputies (93\%), 80 Heads of Departments (93\%), 40 Secretaries (93\%), and 38 Accounts clerks (88\%). On the average, $92 \%$ of the respondents concurred that prioritizing purchase of ICT equipment though would be seen as expensive at the initial cost but would be cost effective as all the clerical work such as processing exams and other school management documents would be done from within the school instead of hiring commercial entrepreneurs.

The present study is supported by the view of a research conducted by Laaria (2013) that observes that the Government of Kenya has formulated a National ICT policy that recognizes that lack of adequate ICT infrastructure has hampered provision of efficient and affordable ICT services in the 
country. The strategy the government has put in place will include provision of infrastructure such as energy and roads; supporting software development; promotion of local manufactures and assembly of ICT equipment and accessories and; provision of incentives for the promotion of ICT infrastructure.

The strategies were equally rated on a likert scale as shown in table 2

Table 2. Strategies of enhancing ICT use in Secondary Schools

Challenges

Strategies

Individual Mean score

Overall M. score

$P \quad$ DP HOD A HOD B SEC ACC/BU AV

1. Inadequate ICT tools

Financial constrain

High maintenance cost

Grants from comm.

$>$ Donation by NGOs

Parents' contribution $\int$

$4.558 \quad 4.465$

4.163

4.465

4.395

4.581

4.438

1. Virus infection Educating staff

2. Unskilled staff $\}$ Organizing w/shops,

Educating staff

3. Neg. attitude Organizing w/shop

$4.302 \quad 3.674 \quad 3.860$

4.069

4.069

4.140

4.019

4. Fear of access of conf. data Educating staff $4.140 \quad 3.767 \quad 4.210$

Personalization of , comp. $\}$ Educating staff

5. Lack of electricity Jnstalling electricity, $3.442 \quad 3.628 \quad 3.883$ power back up

$\begin{array}{llll}4.372 & 3.581 & 4.395 & 4.078\end{array}$

$3.628 \quad 3.674 \quad 4.140$

3.733

Key: $\mathbf{P}=$ Principals, DP - Deputy Principals, HOD A = HOD Academics, HOD B = HOD Boarding, $\mathbf{S E C}=$ Secretaries, BU/ACC $=$ Bursars/ Accounts clerks.

\section{Classification of strategies based on limiting factors as observed by respondents}
4.1---5.0 = Most effective
3.1 -4.0 = Effective
2.1 $-\mathbf{3 . 0}=$ Less effective
$\mathbf{1 . 0}-\mathbf{2 . 0}=$ Least effective

During interview with principals, majority of the principals maintained that they were looking for grants from both the government and donor organizations. This strategy that was rated at a mean of 4.558 on a likert scale was to help bring more computers to school system. The head teachers also maintained that they were also requesting for grants from NGOs to help get new computers. Most of the Principals maintained that they were writing proposals through their local politicians to help their schools get grants for purchasing computers or seek assistance directly from the donors. This would help reduce the challenges of inadequate ICT tools and high maintenance cost of ICT appliances that school usually face. The other respondents; the Deputies (4.465), HOD Academics (4.163), HOD Boarding (4.465), Secretaries (4.395) and the clerks equally maintained that a spirited effort need to be mounted by the school administration to source for funding from well wishers, donor agencies and from the government. 
The findings of this study is supported by a study carried out by Laaria (2013) that noted that the Government of Kenya expects the private sector to play an important role in meeting the universal access targets through increased investment, The Governments' strategy will be to promote investment in rural and other un-served areas through provision of incentives and a universal service fund for the ICT sector will be set up to complement private sector initiatives towards meeting universal access targets. The purpose of the fund will be to substitute the cost of ICT infrastructure rollout and expansion to un-served and under-served areas by operators in the sector. The fund will also target training in ICT services.

Most principals noted that they were organizing in-house workshops and seminars on the use of ICT in school systems. Such seminars were meant to make the staff understand the usage of ICT as well as to know how to use various equipments in the day to day running of the school affairs. The principals who rated workshops and seminars at a mean of 4.140 maintained that such workshops were important because most staff members were semi-illiterate when it comes to ICT usage. The principals also indicated that they were aware that some of members their staff had not trained on IT and that warrant the workshops and seminars. HOD Academics, HOD Boarding, and Accounts clerks whose ratings were 4.210, 4.372, and 4.395 respectively also maintained that a number of teachers feel shy to use computers for examination and result analysis due to limited knowledge in such packages as use of excel to analyze data. They therefore decline to use computers, pass the raw data to HOD Academics or tell a teacher skilled in the area to help them. Some principals maintained that they were currently educating their staff on the importance of ICT on the school administration. This sensitization was necessary because it is a new approach to administration which was surprising many staff.

This study supports the view by Okumbe (1998), who posit that in order to perform its role effectively and efficiently, an educational system must have a foresighted educational leadership which is based on sound management principles and techniques. The functions of educational management include procuring the resources necessary for achievement of the objectives such as source of funds, appropriate curriculum and congenial human resource and to influence and stimulate maximum potentials from both staff and students, strive to have administrators, support personnel and their staff with highest levels of professional development. On the whole, the respondent concurred that it is the administrations prerogative to source for funding from donors, communities, and well wishers to in order to help in the purchase of computers, printers, scanners among many other ICT related devices to help run the management functions of a school. 
Document analysis was done by the researcher to check on the presence and use of ICT related facilities such as functioning computers, printers, computer linkage to various departments, internet connectivity, school cellular phones, documentation by use of ICT and any other ICT related facilities. This was done by categorizing schools into various sub sectors such as Mixed day Schools, girls Boarding Schools and Boys Boarding Schools. Conclusions from the observation schedule indicated that $90 \%$ of both Boys and Girls Boarding schools had majority of their departments well equipped with computers, printers, and or photo printing machines. The examinations departments in such schools were fully equipped to process exams, school and examinations time-tables, analyze students' results either as a single set or cumulatively at the end of the year. In some boarding schools $68 \%$ of the Principals had purchased laptops that they were using to keep confidential information like BOM minutes, procurement records, and staff returns. The Principals that were using laptops were seen to be quite at ease with using the device. There was a wide disparity as compared to majority of mixed schools, $72 \%$, that had either one computer at the examinations' office being shared by the other departments.

What is most appreciated from the study is that in all the 43 schools sampled, electricity had been installed. The major challenge was the continuous power blackout for those that did not have power backup, or power disconnection due lack payment of power bills. What is appreciated again is that in all the schools, an effort was being made to delink the office of the secretaries from examination management and processing of examinations progress records. 92\% of the secretaries confirmed that their task is to handle administrative duties from the Principals office. All the secretaries sampled confirmed that they had ICT basic skills that were helping them to operate computers without any problem. A few of the Accounts clerks (8\%) had their computers connected to the Principals computer such that any entry or deletion would be detected at the Principals office without necessarily notifying the Principal. The other (92\%) of the Accounts clerks had computers that were not inter connected although they were still entering financial records in the computers. This observation confirms the views given by the Principals during an interview that a number of school documents are being stored in computer files and this makes storage, access and retrieval quite easy.

Another area of concern was to observe how school managers store and process students personal data, staff returns and use of internet. With all the sectors going online, Form Four enrolment details with photos attached to them were being sent to Kenya National Examinations online. This is an area where the principals rated highly (86\%), with only a handful (12\%) getting assistance from commercial market. Internet connectivity was seen to be a big 
challenge as a number of schools were using modem, which according to Principals was quite expensive.

In conclusion, the ideas that have been discussed in this study suggest that ICT use has impacted on educational practice in education to date in quite small ways but that the impact will grow considerably in years to come and that ICT use will become a strong agent for change among many educational management practices.

\section{Summary, Conclusion and Recommendation Summary}

The study established that there were several strategies that were being used by schools to enhance the use of ICT in the school management system. Among the major steps were, Looking for grants from the government to buy computers, seeking for ICT grants from NGO and using parents contributions for buying computers. Other steps includes; prioritizing ICT equipments in the school board of management, organizing workshops on IT and educating the staff on the importance of ICT on the school administration.

\section{Conclusion}

Data analysis and interpretations show that secondary schools were embracing the use of ICT in managing their school systems. Based on the findings of the study the following conclusions were made. The study concludes that ICT is vital for usage in monitoring activities on students personal and health records, students academic progress, students finance records, procurement records, and financial transaction records.

The study also concludes that ICT is vital for monitoring other areas like staff personal data records, school policies and history, school academic performance records, school's academic performance records, students' subject choices records and school facilities and equipment records. Such areas were considered important for the survival of a school system and employing ICT was necessary so as to ensure smooth running of the school systems.

The study established that schools were taking several steps to help in enhancing ICT delivery. Among such steps were, Looking for grants from the government to buy computers, seeking for ICT grants from NGO and using parents contributions for buying computers. Other steps includes; prioritizing ICT equipments in the school board of management, organizing workshops on IT and educating the staff on the importance of ICT on the school administration. From the above findings, the study concludes that more support should be given to school to enable them achieve their dream 
of fully implementing the usage of ICT in the management of school activities.

\section{Recommendation}

The study recommends that all areas in the school system should be connected with ICT so as to enable easy access and proper monitory system.

The study equally recommends that inter-linkage should be done in all areas in the school to ensure work efficiency.

The study also recommends that effort should be made by the government to post and provide teachers skilled in ICT to each school to impart ICT skills to school managers.

School should appeal to non-governmental organizations, private sectors, individuals and industries to assist in supplementing and substituting obsolete ICT equipment like projectors and other software packages to aid school management.

\section{Recommendation for Further Studies}

The following recommendations for further studies were made;

a). A study should be conducted to establish the differences in managing ICT as compared to non-ICT facilities in secondary schools.

b). A study should be conducted to establish the link between ICT managers' training and effective leadership.

\section{References:}

1. Al- Sharifa, M. (2012). Leadership Practices of Kuwaiti Secondary School Principals for Embedding ICT. PHD Thesis. Gult Comparative Education Society (GCES). Quensland University of Technology.

2. Boit M.J and Menjo K.D (2012). The Challenges of using Information Communication Technology (ICT) in School Administration in Kenya. Journal of Emerging Trends in Educational Research and Policy Studies (JETERAPS) 3 (1): 55-60:

3. Borg, N. and Gall, M. (1993). Educational Research: An Introduction. New York: Longman Publishers. $4^{\text {th }}$ Ed.

4. Borg, R, Gall, M, and Gall, J (2006) Education Research: An Introduction. New York: Longman Publishers. $8^{\text {th }}$ Edition.

5. Campbell, D \& Sellbom, M. (2002). 'Barriers to Adopting Technology for Teaching and Learning.’ Educase Quarterly, 25 (2), 22-28.

6. EFA Global Monitoring Report (2012). Youth and Skills: Putting education to work. Paris, France (UNESCO). http:unescdoc,unesco.org/images/0021/002175/217509e.pdf.

7. Denscombe, M. (1983). The Good Research Guide for Small Scale Research Projects. Open University Press, London. 
8. Farrel, G. (2007). ICT in education in Kenya. http//www.infodev.org.

9. Frankel, J.R \& Wallen, N. E. (1993), How to design and Evaluate Research in Education ( $2^{\text {nd }}$ Edition). McGraw-Hill, New York.

10. Genov, N (1999). Managing Transformations in Eastern Europe. Publication of the Personal and Institutional Strategies for Management of Transformation Risks in Central and Eastern Europe" Project. UNESCO- MOST, Paris. Regional and Global Development Sofia.

11. Government of Kenya (2006). Education Sector Policy Overview Papers: Government Printers, Nairobi.

12. Government of Kenya, (2005). Siaya District Strategic Plan 2005-2010. Nairobi: National Coordination Agency for Population and Development, Ministry of Planning and National Development.

13. Government of Kenya (2005). Session Paper. No 1 of 2005 on a policy Framework for Education, Training and Research; Government Printer. Nairobi, Kenya.

14. Government of Kenya (2006). National ICT Policy. Government Printer. Nairobi, Kenya.

15. Government of Kenya, (2002) Siaya District Development Plan. Nairobi, Government Printer.

16. Gurr, D., (2004). ICT, Leadership in Education and E- Leadership. Discource: Studies in the Cultural Politics of Education. 25 (11) 113124.

17. ISRJ (2011). Indian Streams Research Journal; Vol 1, Issue IV; Information and Communication Technology (ICT); Ifotech. Com.

18. Kenya School Net, (2003). Preparing a Workforce for the Evolving Information Economy: A Survey on ICT Access and Use in Kenya Secondary Schools, Nairobi: Summit Strategies Limited.

19. Kiptalam G. K \& Rodrigues A.J (2010). Internet Utilization: A Case of Connected Rural and Urban Secondary Schools in Kenya. International Journal of Computing and ICT Research, Vol. 4. No 1, June 2010: http//www.ijcir.org/volume4-number 1/article6.pdf.

20. Kipsoi E. J, Chan’gach j.k \& Sang C. H (2012). Challenges Facing Adoption of Information Communication Technology (ICT) in Kenya. Journal of Sociological Research. 3 (1). Htt://dx.doi.org//10.5294/jsr.v3il.1882.

21. Kombo, D.K \& Tromp, D.L.A. (2006). Proposal and Thesis Writing: An Introduction. Nairobi: Paulines Publications Africa.

22. Kothari, C. R. (2004). Research Methodology: Methods and Techniques. New Age International (P) Ltd.

23. Laaria, M. (2013). Leadership challenges in the implementation of ICT in enhancing management of public secondary schools, Kenya. Journal 
of Education and Learning vol 2 .No $1: 2013$ 32-43 http//dx.doi.org/10.5539/eilv2nlp32

24. Makau, B.M \& IDRC, (1990). Computers in Kenya's Secondary Schools: Case study of an innovation in education, Ontario: IDRC.

25. Manduku. J, Koskey, A \& Sang, H. (2012). Adoption and use of ICT in enhancing management of public secondary schools: A survey of Kesses Zone secondary schools in Wareng District of Wasin Gishu County, Kenya.

26. Mark Gronow, (2007). ICT Leadership in School Education; A Paper presented to the Australian Catholic University Conference. The Sofitel Wentworth, Sydney, Australia.

27. Ministry of Education Science and Technology (MOEST), (2005): Sessional Paper no.1 of 2005: A Policy Framework for Education, Training and Research, 2005; Nairobi; Government Printer.

28. Ministry of Education Science and Technology (2008). Final Report on the Kenya Education Management Capacity Assessment (KEMACA), Nairobi, Kenya.

29. MOEST (2005): Kenya Education Sector Support Programme: 20052010. Delivering Quality Equitable Education and Training to All Kenyans; 2005 Draft. Nairobi; Government Printer

30. MOEST (2005).ICTs in Education Options Paper 2005- Ministry of Education, Science And Technology. Government of Kenya.

31. Mohammad, Y., (2006). Factor Influencing the Implementation of ICT in Jigawa States Schools, Nigeria. Unpublished M. Ed. Thesis, University of Ilorin.

32. Mouly, G. (1993). The Science of Educational Research. New York American Book Company

33. Mugenda, .M. O and Mugenda A.G. (1999). Research Methods: Quantitative and Qualitative Approaches. Nairobi: Nairobi African Center for Technology (ACTS).

34. Mugenda, O. M and Mugenda A. G (2003). Research Methods; Quantitative and Qualitative Approaches: Acts Press, ICRAF Complex, United Nations Avenue, Nairobi.

35. Nic Steyn and Bert (2000). Statistical Package for Social Science. New York Melirant Hil.

36. Nwagwu, N. A, (1995). The development and Management of Records in the Nigerian Education System in Data Management in Schools and other Issues. Ehiametalor, E.T (ed) Benin-City, Ilupeju Press Limited.

37. Nwosu, A.A, (2003). Integrating ICT into STM Classroom: Status and Implications. Proceeding of the $44^{\text {th }}$ Stan Conference 56 to 60 .

38. Odera, F. Y. (2002) A study of Computer Integrated Education in Secondary Schools in Nyanza Province, Kenya. 
39. Ogonsola, L. A (2005). Information Communication Technologies and the Effects of Globalization: Twenty-First Century "Digital Slavery” for Developing countries- Myth or Reality? : Electronic Journal of Academic and Special Librarianship 6 (1-2) pp 1-10.

40. Okumbe J. A. (1998). Educational Management: Theories and Practice. Nairobi: Nairobi University Press.

41. Osodo, J. (1999). Visualization skills incorporation into a Biology undergraduate courses. University of Natal, Durban, South Africa.

42. Osodo, J. Indoshi F.C, Ongati, O. (2010). Attitudes of students and teachers towards use of computer technology in Geography education. Educ. Res.1(5).

43. Republic of Kenya (2005b) Siaya District Strategic Plan (2005-2010) for implementation of the National Population Policy for Sustainable Development; Ministry of Planning and National Development. Government Printers; Nairobi

44. Schiller, J. (2002). Surfers or Spectators? Principals and ICT. Principal Matters. March 30-31.

45. Siaya County (2009). General Information on Kenya: County Fact Sheets; Nairobi; Government Printer.

46. Tanui, E.K (2003). Relative effects of a computer-based instruction in accounting on students' achievement, perception of classroom environment and motivation in secondary schools in Kenya. Doctoral Thesis , Egerton University, Njoro, Kenya.

47. Tanui,E.K, Kiboss, J.K, Walaba,A.A. \& Nassiuma, D. (2008). Teacher's changing roles in computer assisted roles in Kenyan secondary schools Education Research and Review Vol. 3

48. Telem, M. (2001). "Computerization of School Administration: Impact on Principals' Role: A Case Study” in Computers in Education, (37) PP 345-365.

49. Tilya, F. N. (2007). Policy Issues in ICT Education and Training. Available online:

50. UNDP (2006). Information Communication Technologies and Development. Available at: http://usdnhq.undp.prg/it4dev/

51. UNDP Evaluation Office (2001). Information Communication Technology for Development. No 5 pp 1-31.

52. World Bank (2007). "Knowledge and Skills for the Information Age: The First Meeting of the Mediterranean Development Forum," in Mediterranean Development Forum.

53. Yusuf, M. O (2005). "Information and Communication Technology" Analyzing the Nigerian National Policy for Information Technology in International Educational Journal (3)PP 316-321 